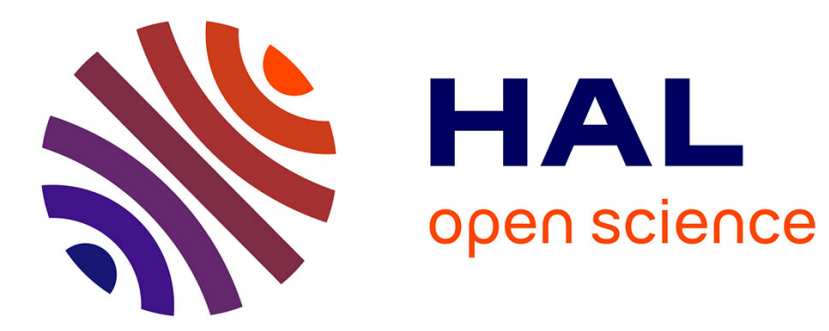

\title{
Sildenafil corrects the increased contractility of rat detrusor muscle induced by alprostadil in vitro
}

\author{
Wesam Bassiouni, Amira Senbel, Xavier Norel, Tahia Daabees
}

\section{To cite this version:}

Wesam Bassiouni, Amira Senbel, Xavier Norel, Tahia Daabees. Sildenafil corrects the increased contractility of rat detrusor muscle induced by alprostadil in vitro. Pharmacological Reports, 2019, 71, pp.659 - 668. 10.1016/j.pharep.2019.03.004 . hal-03486364

\section{HAL Id: hal-03486364 https://hal.science/hal-03486364}

Submitted on 20 Dec 2021

HAL is a multi-disciplinary open access archive for the deposit and dissemination of scientific research documents, whether they are published or not. The documents may come from teaching and research institutions in France or abroad, or from public or private research centers.
L'archive ouverte pluridisciplinaire HAL, est destinée au dépôt et à la diffusion de documents scientifiques de niveau recherche, publiés ou non, émanant des établissements d'enseignement et de recherche français ou étrangers, des laboratoires publics ou privés.

\section{다)(1) $(5$}

Distributed under a Creative Commons Attribution - NonCommercial| 4.0 International 


\title{
Sildenafil Corrects the Increased Contractility of Rat Detrusor Muscle Induced by Alprostadil In-Vitro
}

\author{
Wesam Bassiouni $^{1}$, Amira Senbel ${ }^{1,2}$, Xavier Norel ${ }^{2}$, Tahia Daabees ${ }^{1}$
}

1 Department of Pharmacology and Toxicology, Faculty of Pharmacy, Alexandria University, Egypt

2 Laboratory for Vascular Translational Sciences, INSERM U1148, X. Bichat Hospital, University Paris XIII, France

\section{Author of correspondence:}

Amira M. Senbel, Ph.D.

Professor of Pharmacology and Toxicology,

Faculty of Pharmacy, Alexandria University, Egypt.

Current address:

LVTS, INSERM U1148, CHU X. Bichat, 46 rue Henri Huchard,

75877 Paris Cedex 18, France.

senbelamira@alexpharmacy.edu.eg

Fax: +2034871317 


\title{
Sildenafil Corrects the Increased Contractility of Rat Detrusor Muscle Induced by Alprostadil In-Vitro
}

\begin{abstract}
Background: Sildenafil (PDE5-inhibitor) and alprostadil $\left(\mathrm{PGE}_{1}\right)$ are used in combination clinically for the management of some cases of erectile dysfunction. Despite the roles of prostaglandins (PG) and NO pathways in contractility of bladder smooth muscle are frequently studied, the effect of sildenafil/alprostadil combination and the crosstalk between NO/cGMP and PG pathways on bladder activity is not documented.

Methods: Organ-bath experiments were performed using isolated rat detrusor muscle. Direct and neurogenic contractions were induced using $\mathrm{ACh}$ and electric stimulation (EFS,4Hz,80V,1ms), respectively. The contractile responses in absence and presence of the tested drugs at different concentrations were compared. Results are expressed as mean \pm SEM $(n=5-7)$.
\end{abstract}

Results: Alprostadil( $0.01-10 \mu \mathrm{M})$ concentration-dependently potentiated $\mathrm{ACh}(100 \mu \mathrm{M})$ - and EFS $(4 \mathrm{~Hz})$ - induced contraction. Maximum potentiation of ACh-contraction in presence of alprostadil was $40 \pm 5 \%$. Sildenafil potentiated ACh-induced contraction at low concentrations $(0.01-1 \mu \mathrm{M})$, but inhibited it at higher ones (10-100 $\mu \mathrm{M})$. IBMX (non-selective PDE-inhibitor, $10 \mathrm{nM}-100 \mu \mathrm{M})$ and SNP (NO-donor, $1 \mathrm{nM}-1 \mathrm{mM}$ ) produced the same biphasic pattern. The potentiatory phase of sildenafil was inhibited by atropine $(0.1 \mu \mathrm{M})$, L-NAME (non-selective NOS-inhibitor, $100 \mu \mathrm{M}$ ), N-PLA (nNOS-inhibitor, 30 $\mu \mathrm{M}$ ) or MB (nonselective GC-inhibitor, $10 \mu \mathrm{M})$. In presence of sildenafil $(0.1 \mu \mathrm{M})$, the concentration-response curve of alprostadil (0.01-10 $\mu \mathrm{M})$ on both ACh and EFS-induced contraction was clearly shifted downward.

Conclusions: A crosstalk between $\mathrm{PGE}_{1}$ and NO/cGMP pathways may exist. At low concentrations only, the effect of sildenafil on bladder contractility is dependent on NO/cGMP. cGMP intracellularly-elevated by sildenafil, may inhibit the activity of PLC and hence the cascade of $\mathrm{EP}_{1}$-receptors, thus masking the hyperactivity of bladder caused by alprostadil, which adds to the advantages of this combination.

Keywords: sildenafil; alprostadil; PGE; urinary bladder; detrusor muscle; NO/cGMP pathway 


\section{Introduction}

The urinary bladder is the organ responsible for storage of urine and micturition. The bladder is a tetrahedron organ, when empty it lies extraperitoneal behind the pubic area [1]. The bladder is divided into two main parts; (a) the body which is located above the orifice of the ureter and (b) the base which consists of the trigone and the bladder neck [2]. The serosa is the outer layer, the detrusor smooth muscle constitutes the body of the bladder, and the urothelium is the innermost layer lining the bladder wall [3]. The major neurotransmitters $\underline{\text { involved in contractility of detrusor smooth muscles are acetylcholine (ACh) and adenosine }}$ triphosphate (ATP). Muscarinic and purinergic receptors activation cause elevation of intracellular calcium $\left(\mathrm{Ca}^{2+}\right)$ level and activation of voltage-dependent L-type $\mathrm{Ca}^{2+}$ channels resulting in contraction of the muscle [4]. The contractile receptors in the detrusor muscles include; muscarinic receptors $\left(\mathrm{M}_{2}\right.$ and $\left.\mathrm{M}_{3}\right)$ which are the dominant ones, and purinergic

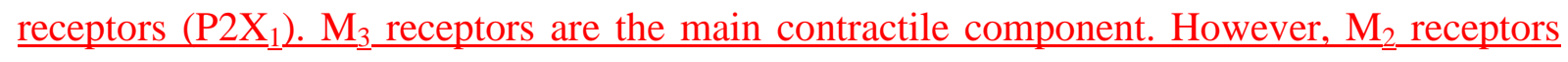
are the more expressed ones and are responsible mainly for the recontraction of the detrusor muscles after relaxation $[5,6]$.

Bladder overactivity and hypoactivity are among the most common disorders of the lower genitourinary tract, in addition to inflammatory conditions and cancer [7]. Overactive bladder $(\mathrm{OAB})$ is defined by the International Continence Society as urinary urgency with accompanying increased daytime urinary frequency and nocturia with or without urgency urinary incontinence [8]. The exact role of endogenous prostaglandins (PGs) in tissues of lower urinary tract is not well elucidated, but various studies have confirmed that exogenous PGs alter the bladder motor activity and micturition reflex in both human and animals [9-12]. The main PGs synthesized in bladder under physiological and pathological conditions are $\mathrm{PGE}_{2}, \mathrm{PGF}_{2 \alpha}, \mathrm{PGI}_{2}$ and $\mathrm{TXA}_{2}$ [13]. $\mathrm{EP}_{1}$ and $\mathrm{EP}_{3}$ receptors are reported to be involved in bladder contraction, while $\mathrm{EP}_{2}$ and $\mathrm{EP}_{4}$ induce relaxation [14]. $\mathrm{PGE}_{2}$ level was found to be higher in patients with overactive bladder $(\mathrm{OAB})$ [15], an effect mainly mediated via $\mathrm{EP}_{1}$ receptors. Alprostadil is a synthetic analog of prostaglandin $\mathrm{E}_{1}\left(\mathrm{PGE}_{1}\right)$. Its main uses involve the management of erectile dysfunction [16] and pulmonary hypertension [17]. Alprostadil has been first demonstrated by Ishii et al. for treatment of erectile dysfunction [18]. However, it has not been approved by the Food and Drug Administration until 1995 when it has been marketed under the brand name Caverject ${ }^{\circledR}$ as intracavernous injection. A year later, it was approved for usage by intraurethral route under the brand name Muse® [16] Alprostadil is also used with success in the management of patent Ductus Arteriosus, intermittent 
claudication, Buerger's disease and Raynaud's phenomenon [19-22]. $\mathrm{PGE}_{1}$ is reported to provoke strong micturition reflexes in dogs and in rabbits [23, 24], and induces contraction of human detrusor muscles [25]. Increased urinary urgency in humans is in fact reported as a side effect of alprostadil [26, 27].

The exact role of nitric oxide/cyclic guanosine monophosphate (NO/cGMP) pathway, on the other hand, is not yet fully understood. Previous studies have reported that NO induces urinary bladder relaxation via guanylyl cyclase (GC)/cGMP pathway [28], while other studies reported that NO enhances detrusor muscle spontaneous contractility via cGMP-independent mechanism [29]. Sildenafil $\left(\right.$ Viagra $^{\circledR}$ ) - used to manage erectile dysfunction and approved by FDA for the management of pulmonary hypertension- is one of the major modulators of NO. Sildenafil is a phosphodiesterase 5 (PDE-5) inhibitor; it inhibits the breakdown of cGMP thus prolongs the action of NO in smooth muscles [30]. Gumrah et al. (2017) proved that sildenafil reduced bladder contractility in rats and Aizawa et al. (2017) showed that sildenafil may improve bladder storage in female rats by exhibiting an inhibitory role on the bladder afferent transduction $[31,32]$.

Lower urinary tract symptoms including erectile dysfunction are frequent problems in older men worldwide, they were reported to be close to $95 \%$ of the population aged over 60 in a survey of 30,000 patients in the USA, UK and Sweden [33]. In 2008, almost $45.2 \%$ of the worldwide populations have been reported to be affected by at least one lower urinary tract symptom including $10.7 \%$ suffering from OAB. The prevalence of lower urinary tract symptoms is expected to be higher in Middle East and estimated to increase by almost 18.4\% in 2018 [34]. Both alprostadil and sildenafil are considered the mainstay of management of erectile dysfunction, and are clinically used in combination in cases unresponsive to sildenafil alone $[35,36]$. The effect of sildenafil/alprostadil combination and the potential crosstalk between NO/cGMP and PG pathways on detrusor muscle contractility as an important component of bladder function is not previously investigated. Therefore, this study aims to evaluate the effect of combining alprostadil and sildenafil on rat detrusor muscle contractility and to investigate the potential mechanism(s) controlling their interaction.

\section{Material and Methods:}

\subsection{Materials}

The chemicals used in this study and their respective sources were as following: (3)isobutyl-1-methyl xanthine (IBMX, Sigma), Acetylcholine chloride (ACh, Sigma), alprostadil 
(Tocris), Atropine sulphate (Merck), Methylene blue (MB, Sigma), NG-Nitro-L-arginine

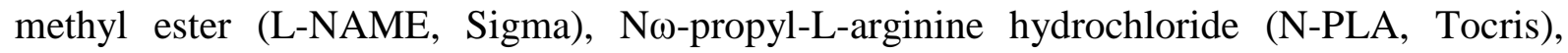
Sildenafil citrate (Viagra ${ }^{\circledR}$, Pfizer), Sodium nitroprusside (SNP, Merck), Thiopentone sodium (vial, Biochimie).

Stock solutions $(2.22 \mathrm{mg} / \mathrm{ml})$ of IBMX and $(1.4 \mathrm{mg} / \mathrm{ml})$ alprostadil were prepared in 95\% ethanol and kept frozen. The obtained final bath concentration of ethanol was less than $1 \% \mathrm{v} / \mathrm{v}$ which showed no significant effect on the studied tissue. Stock solutions $(6.76 \mathrm{mg} / 100$ $\mathrm{ml})$ of atropine sulphate, $(0.76 \mathrm{mg} / \mathrm{ml})$ of N-PLA, $(26.2 \mathrm{mg} / \mathrm{ml})$ of SNP and $(6.67 \mathrm{mg} / \mathrm{ml})$ of sildenafil citrate were prepared in distilled water and kept frozen. SNP was kept in dark bottle and subsequent dilutions were made in aluminum foil-covered vials. Solutions $(0.32 \mathrm{mg} / \mathrm{ml})$ of MB and $(2.7 \mathrm{mg} / \mathrm{ml})$ of L-NAME were prepared in distilled water and kept frozen. A fresh solution $(18 \mathrm{mg} / \mathrm{ml})$ of ACh (Sigma) was prepared daily in Krebs solution.

\subsection{The isolated rat detrusor smooth muscle}

Experiments were carried out on male albino Wistar rats weighing 250-270 g. The animals were obtained from the Alexandria University Faculty of Pharmacy Animal House. The rats were housed in animal cages, in groups under normal environmental conditions of day light and temperature with access to water and chow. Study protocols comply with the guidelines for the proper conduct of animal experiments and are approved by the local Animal Care and Use Committee (ACUC). All applicable international, national, and institutional guidelines for the care and use of animals were followed. Preparation of the muscle was performed as described by Luheshi and Zar (1991) [37]. Rats were anesthetized by intraperitoneal injection of thiopentone $(50 \mathrm{mg} / \mathrm{kg})$ and then sacrificed by exsanguination. In order to expose and isolate the urinary bladder, the lower abdomen was opened and the bladder separated from associated connective tissues and blood vessels. The bladder was then excised above its trigone to isolate only the detrusor muscles of the bladder away from its neck and urethral sphincter, fixed in a petri dish and two lateral incisions along its longitudinal axis were made and the bladder was unfolded giving rectangular sheet which was cut longitudinally to give two strips of detrusor muscle $2 \times 15 \mathrm{~mm}$. The detrusor muscle was fixed at one end between two parallel platinum electrodes 4 to $5 \mathrm{~mm}$ apart and mounted in a $10 \mathrm{ml}$ organ bath containing Krebs solution (Composition in $\mathrm{mM} ; \mathrm{NaCl} 118, \mathrm{KCl}$ 4.7. $\mathrm{CaCl}_{2}$ 2.5, $\mathrm{MgSO}_{4} .7 \mathrm{H}_{2} \mathrm{O}$ 1.2, $\mathrm{KH}_{2} \mathrm{PO}_{4} 1.2, \mathrm{NaHCO}_{3} 25$ and glucose 11), kept at $37^{\circ} \mathrm{C}$ and continuously aerated with $95 \% \mathrm{O}_{2}$ and $5 \% \mathrm{CO}_{2}$. The other end was tied and attached to a 
force displacement transducer (Grass FT-03) which in turn was connected to a computerized data acquisition system through an MLAC11 Grass adapter cable. Tension studies were performed using Lab Chart-7 pro software (Power Lab 4/35, model ML 866/P; AD Instrument Pty Ltd, Castle Hill, Australia). The tissue was left to equilibrate for 60 min under a resting tension of $0.5 \mathrm{~g}$ during which the physiological solution was replaced each $15 \mathrm{~min}$. Meanwhile, time-matched control experiment was conducted over the duration of the experiment.

The contractile responses to ACh (in g tension) in absence and presence of the tested drug were measured and the percentage change from control was calculated. The halfmaximum effective concentration $\left(\mathrm{EC}_{50}\right)$ value is calculated from the concentration response curve of the agonist. Changes in relative potency of ACh on detrusor muscles are determined by comparing $\mathrm{EC}_{50}$ values of $\mathrm{ACh}$ in absence and presence of the tested drug. For electric field stimulation (EFS) experiments, each strip was subjected to increasing frequencies (1-16 $\mathrm{Hz}$; voltage $80 \mathrm{~V}$, pulse duration $1 \mathrm{~ms}, 3$ min interval) and submaximal frequency (4 Hz) was used for further experiments. Stimulation was provided using two parallel platinum electrodes which were attached to a Grass electronic stimulator (Model S 48). After incubation with the studied drug, the frequency response curve or the submaximal frequency was repeated. The contractile responses in absence and presence of the tested drug were measured and the percentage change from control was calculated.

First, modulators of NO/cGMP pathway were tested, where concentration response curves of sildenafil $\left(10^{-8}-10^{-4} \mathrm{M}\right)$, IBMX (nonselective PDE inhibitor, $10^{-8}-10^{-4} \mathrm{M}$ ) and SNP $\left(10^{-9}-10^{-3} \mathrm{M}\right)$ were conducted and their effects on ACh $\left(10^{-4} \mathrm{M}\right)$ and EFS (4 Hz)-induced contraction were recorded and compared to time-matched control over the experiment duration. Effect of some selected blockers on sildenafil's action was investigated to determine its mechanism of action. This was followed by the evaluation of alprostadil/sildenafil combination in modulating rat detrusor muscles contractility.

\subsection{Data Analysis and Statistics}

All the obtained results are expressed as mean \pm SEM. Values between parentheses (n) represent the number of animals in each group. For analysis of unpaired data, the student's ttest nonparametric Mann-Whitney U test was used, while for multiple comparison, one-way analysis of variance (ANOVA) was used followed by Kruskal-Wallis test Dunnett's post-test. 
Statistical significance was considered at the level of $p<0.05$. Analysis was performed using computer software program GraphPad Prism 6.01.

The contractile responses to ACh or EFS (in g tension) in absence and presence of the tested drug were measured and the percentage change from control was calculated as follows;

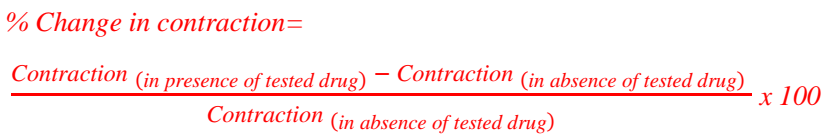

\section{Results:}

\subsection{Effect of sildenafil, IBMX and SNP on ACh and EFS-induced contraction}

Sildenafil caused a significant potentiation of ACh-induced contraction at lower concentration with a percentage potentiation of $10.47 \pm 2.60 \%$ at $10^{-8} \mathrm{M}$ sildenafil, while upon increasing sildenafil concentration to $\left(10^{-5}\right.$ and $\left.10^{-4} \mathrm{M}\right)$, it started to cause a significant inhibition of ACh-induced contraction. Sildenafil $\left(10^{-4} \mathrm{M}\right)$ significantly inhibited AChinduced contraction by $76.96 \pm 2.00 \%$. In case of EFS, sildenafil caused a significant potentiation of EFS-induced contraction at lower concentrations $\left(10^{-7}-10^{-6} \mathrm{M}\right)$ with a maximum attained potentiation of $31.53 \pm 7.62 \%$ at $10^{-6} \mathrm{M}$, and significantly inhibited EFSinduced contraction at high concentration $\left(10^{-4} \mathrm{M}\right)$ by $44.40 \pm 2.72 \%(p<0.05)$ (Figure 1). The same biphasic pattern appeared using IBMX which caused a significant potentiation of ACh-induced contraction at low concentrations $\left(10^{-7}\right.$ and $\left.10^{-6} \mathrm{M}\right)$ with a maximum attained potentiation of $25.87 \pm 5.02 \%$ at $10^{-6} \mathrm{M}$, while upon increasing IBMX concentration to $\left(10^{-5}\right.$ and $\left.10^{-4} \mathrm{M}\right)$, it started to cause an inhibition; IBMX $\left(10^{-4} \mathrm{M}\right)$-significantly inhibited AChinduced contraction by $42.47 \pm 6.10 \%$. In case of EFS, IBMX caused a significant potentiation of EFS-induced contraction at low concentrations $\left(10^{-8}-10^{-6} \mathrm{M}\right)$ with a maximum attained potentiation of $41.44 \pm 3.31 \%$ at $10^{-6} \mathrm{M}$, followed by a significant inhibition at higher concentrations $\left(10^{-5}\right.$ and $\left.10^{-4} \mathrm{M}\right)$. IBMX $\left(10^{-4} \mathrm{M}\right)$ significantly inhibited EFS-induced contraction by $44.64 \pm 4.82 \% \underline{(p<0.05)}$ (Figures $2 \& 3$ ).

Similarly, SNP caused a significant potentiation of ACh-induced contraction at low concentrations $\left(10^{-9}-10^{-6} \mathrm{M}\right)$ with a maximum attained potentiation of $26.05 \pm 4.18 \%$ at $10^{-6} \mathrm{M}$. Upon increasing SNP concentration to $10^{-3} \mathrm{M}$, it significantly inhibited AChinduced contraction reaching a maximum of $13.27 \pm 1.89 \%$. In case of EFS, SNP also caused a significant potentiation of EFS-induced contraction at low concentrations $\left(10^{-9}-10^{-6} \mathrm{M}\right)$ with a maximum attained potentiation of $22.63 \pm 2.19 \%$ at $10^{-6} \mathrm{M}$, followed by a significant inhibition 
at higher concentration where SNP $10^{-3} \mathrm{M}$ caused $23.43 \pm 3.26 \%$ inhibition $\underline{(p<0.05)}$ (Figures $4 \& 5)$.

\subsection{Modulatory role of atropine, L-NAME, N-PLA and methylene blue on sildenafil's} action on EFS-induced contraction

Effect of atropine $(0.1 \mu \mathrm{M})$, L-NAME (NO synthase 'NOS' inhibitor, $\left.10^{-4} \mathrm{M}\right)$ [38], NPLA (neuronal NOS 'nNOS' inhibitor, $3 \times 10^{-5} \mathrm{M}$ ) [39] or MB (nonselective GC inhibitor, $10^{-5}$ M) [40] on sildenafil's action on EFS-induced contraction of rat detrusor muscles was tested. Atropine significantly inhibited EFS-induced contraction by $30.19 \pm 5.92 \%$, while both LNAME and MB significantly potentiated EFS-induced contraction by $16.38 \pm 3.18 \%$ and $20.23 \pm 2.82 \%$ respectively. On the other hand, N-PLA produced no significant effect $(p<$ $\underline{0.05)}$. In combination with sildenafil, all the tested blockers or inhibitors (atropine, L-NAME, N-PLA and $\mathrm{MB}$ ) caused a significant inhibition of sildenafil-induced potentiation at concentrations $\left(10^{-8}-10^{-5} \mathrm{M}\right)$ of sildenafil, i.e. the potentiatory effect of sildenafil was masked. As for the higher concentration $\left(10^{-4} \mathrm{M}\right)$ of sildenafil which inhibited EFS-induced contraction; atropine produced no significant effect, while L-NAME, N-PLA and MB significantly potentiated the inhibitory effect of sildenafil $\underline{(p<0.05)}$ (Figure 6).

\subsection{Effect of sildenafil on alprostadil-induced potentiation of ACh and EFS-induced contraction}

Effect of alprostadil $\left(10^{-9}-10^{-5} \mathrm{M}\right)$ was tested on the contractile effect of a submaximal ACh concentration of $10^{-4} \mathrm{M}$ and a submaximal frequency of $4 \mathrm{~Hz}$ on rat detrusor muscles and compared to time-matched control over the duration of the experiment. Alprostadil caused a concentration-dependent potentiation of both ACh and EFS-induced contraction with a maximum attained potentiation of $40.01 \pm 5.29 \%$ and $25.32 \pm 4.61 \%$ respectively in presence of $10^{-5} \mathrm{M}$ alprostadil. A concentration of $10^{-7} \mathrm{M}$ sildenafil which produced a submaximal potentiatory effect of $28.21 \pm 3.9 \%$ on EFS-induced contraction was chosen and its effect on alprostadil-induced potentiation of ACh and EFS-induced contraction of rat detrusor muscles was tested.

Sildenafil caused a significant inhibition of alprostadil's potentiatory effect of both ACh and EFS-induced contraction at concentrations $\left(10^{-8}-10^{-5} \mathrm{M}\right)$ of alprostadil. Sildenafil significantly decreased the maximum attained potentiation of ACh-contraction induced by $10^{-}$

${ }^{5} \mathrm{M}$ alprostadil from $40.01 \pm 5.29 \%$ to $23.53 \pm 4.66 \%$, but was still significant from control. On 
the other hand, in case of EFS, sildenafil significantly decreased the maximum attained potentiation of EFS-contraction induced by $10^{-5} \mathrm{M}$ alprostadil from $25.32 \pm 4.61 \%$ to $6.84 \pm 5.77 \%$ which became not significant from control i.e. sildenafil completely abolished the potentiatory effect of alprostadil even at the highest concentration $(p<0.05)$ (Figure 7).

\section{Discussion}

The bladder is divided into two main parts; (a) the body which is located above the orifice of the ureter and (b) the base which consists of the trigone and the bladder neck [32]. The serosa is the outer layer, the detrusor smooth muscle constitutes the body of the bladder, and the urothelium is the innermost layer lining the bladder wall [33]. The major neurotransmitters involved in contractility of detruser smogth muscles are acetyleholine (ACh) and adenosine triphosphate (ATP). Muscarinic and purinergic receptors activation eatuse elevation of intracellular calcium $\left(\mathrm{Ca}^{2+}\right)$ level and activation of voltage-dependent $\mathrm{L}$ type $\mathrm{Ca}^{2+}$ channels resulting in contraction of the muscle [34]. The contractile receptors in the detrusor muscles include; muscarinic receptors $\left(\mathrm{M}_{2}\right.$ and $\left.\mathrm{M}_{3}\right)$ which are the dominant ones, and purinergic receptors $\left(\mathrm{P} 2 \mathrm{X}_{1}\right) . \mathrm{M}_{3}$-receptors are the main contractile component. However, $\mathrm{M}_{2}$ receptors are the more expressed ones and are responsible mainly for the recontraction of the detrusor muscles after relaxation $[35,36]$.

Prostaglandins have been reported to play a major role in lower urinary tract function. The exact role of endogenous PGs in different tissues of lower urinary tract is not well elucidated, but various studies have confirmed that exogenous PGs alter the bladder motor activity and micturition reflex in both human and animals [10]. It was originally shown that vesical distension and pelvic nerve stimulation and $\mathrm{M}_{5}$ receptor activation, evoke a release of $\mathrm{PGE}_{2}$ into the pelvic venous blood of anesthetized dogs [41-43]. In line, intra-arterial administration of $\mathrm{PGE}_{2}$ induced a significant decrease of the threshold micturition volume [44]. Moreover, Kondo et al. (1983) reported that micturition was most frequently provoked in dogs by the intravenous administration a derivative of $\mathrm{PGE}_{1}$ among various other prostanoids tested [23]. In the current study, alprostadil caused potentiation of both ACh and EFS-induced contraction, indicating that $\mathrm{PGE}_{1}$ may be involved in cholinergic and neuronally-mediated contraction of detrusor muscles. This effect also explains the increased micturition reflexes observed in animals [23, 24], and increased urinary urgency reported in humans caused by alprostadil [26, 27]. These results are consistent with those previously reported by Palea et al. (1998) who showed that PGE $_{1}$ induces contraction of human detrusor 
muscles [25]. Boie et al. (1997)-have reported that $\mathrm{PGE}_{1}$ effect involves the activation of all PGs receptors of the E-series $\left(\mathrm{EP}_{4}>\mathrm{EP}_{3}>\mathrm{EP}_{2}>\mathrm{EP}_{1}\right)$ [45]. Taking into consideration that alprostadil potentiated the effect of ACh more than that of EFS, and that ACh-via activating $\mathrm{M}_{5}$ receptors- induces release of $\mathrm{PGE}_{2}$ in the urothelium [43], an additive activation of Ereceptors can be assumed in the presence of alprostadil. $\mathrm{M}_{3}$ receptors on detrusor muscle are $\mathrm{G}_{\mathrm{q}}$-coupled which activates phospholipase $\mathrm{C}$ (PLC) with the formation of inositol 1,4,5trisphosphate (IP3) and diacylglycerol (DAG), while $\mathrm{M}_{2}$ receptors are $\mathrm{G}_{\mathrm{i}}$-coupled which inhibits cyclic adenosine monophosphate (cAMP)/cAMP-dependent protein kinase (PKA) and both in turn result in elevating the intracellular $\mathrm{Ca}^{2+}$ level $[5,6]$. Alprostadil in detrusor muscles may involve the activation of $\mathrm{EP}_{1}$ and $\mathrm{EP}_{3}$ receptors coupled to $\mathrm{G}_{\mathrm{q}}$ pathway, with subsequent induction of IP3 response [14]. $\mathrm{EP}_{3}$ receptors may also act via activating $\mathrm{G}_{\mathrm{i}}$ resulting in elevation of intracellular $\mathrm{Ca}^{2+}$ level [46].

Nitric oxide- on the other hand- is reported to induce relaxation of bladder neck and external urethral sphincter $[47,48]$. Previous clinical studies showed that PDE-5 inhibitors, especially tadalafil, are useful for management of lower urinary tract symptoms, tadalafil has been approved in 2011 for management of benign prostatic hyperplasia [49] Besides, several studies reported the efficacy of tadalafil use in management of OAB symptoms and improving the quality of life in adults [50]. Reges et al. (2013) reported that the systemic reduction of NO (by i.v. injection of L-NAME) causes detrusor overactivity [51], which is consistent with the results of the current in-vitro study. In an attempt to clarify the possible role of NO in mediating the effect of PGs on rat detrusor muscles, the effect of NO modulators; sildenafil, IBMX (nonselective PDE inhibitor) and SNP (NO donor) on both cholinergic and neuronallymediated contraction of detrusor muscles was investigated. All of the tested compounds showed the same pattern of effect on both ACh and EFS-induced contraction; the low concentrations of the tested compounds caused a slight albeit significant potentiation of both ACh and EFS-induced contraction, while at high concentrations, they showed a strong significant inhibition. Although statistically significant, the inhibitory effect of SNP is much lower than that of sildenafil and IBMX. This finding supports the previous reports by Moon (2002) and Yanai et al. (2008) who suggested that NO may cause relaxation of human and guinea pig detrusor muscles preceded by contraction and this contractile effect is cGMPindependent involving $\mathrm{Ca}^{2+}$ release from intracellular stores [29, 52]. Moreover, Longhurst et al. (1997) showed that selective PDE-5 inhibitor potentiated cholinergic-mediated contraction of guinea pig detrusor muscles [53]. In contrast, other studies have reported that NO provokes 
only a relaxant effect on human detrusor muscles [28]. A report by Oger et al. (2010) showed that sildenafil induces human detrusor muscle relaxation via cGMP and cAMP-dependent pathways and also involves cross talking with potassium $\left(\mathrm{K}^{+}\right)$channels signaling pathway [54], and Aizawa et al. (2017) showed that the NO/cGMP pathway plays an inhibitory role on the bladder afferent nerve transduction [32].

In the current study, the effect of sildenafil in presence of L-NAME (nonselective NOS inhibitor) or N-PLA (selective nNOS inhibitor) was investigated. In presence of each inhibitor, the potentiatory effect of low concentrations of sildenafil was inhibited, suggesting that it may be actually NO-dependent, while the inhibitory effect of the high concentrations of sildenafil was unexpectedly potentiated rather than inhibited, indicating the involvement of mediators other than NO in the effect of these higher concentrations. Moreover, MB (nonselective guanylate cyclase GC inhibitor) showed the same pattern of effect as L-NAME and N-PLA; it inhibited sildenafil's potentiatory effect and potentiated its inhibitory effect on rat detrusor muscles, indicating that the potentiatory effect of sildenafil on detrusor contractility may be not only dependent on NO but also on cGMP levels which may activate voltage-independent $\mathrm{Ca}^{2+}$ channels and inward current upon activation of muscarinic receptors [55]. In order to investigate the involvement of muscarinic receptors in sildenafil's action, the muscarinic receptors were blocked using atropine in a concentration that causes less than $50 \%$ blockade. It was observed that, in presence of atropine, the potentiatory effect of sildenafil on rat detrusor muscles was inhibited, while its inhibitory effect was not affected. These results suggest that the potentiatory effect of sildenafil- which is NO/cGMP dependentmay depend on stimulation of inward $\mathrm{Ca}^{2+}$ current via muscarinic receptors activation. We cannot exclude that muscarinic receptor activation, specifically $\mathrm{M}_{5}$, is a driver for NO release from the urothelium [56], which may explain this observation concerning atropine blocking the NO-dependent phase of sildenafil. This observation also proves that sildenafil at higher concentrations acts by a mechanism that is not only NO/cGMP-independent but also cholinergically-independent. Since sildenafil is known to possess other mechanisms of actions such as inhibition of adrenergic alpha receptors in tissues of the lower genitourinary system [57], we can assume that in absence of NO and/or cGMP, the effect of sildenafil on alpha receptors in bladder cells becomes predominant leading to the observed increased relaxation. It is to be mentioned that alpha-1 receptors are reported to be expressed in the urothelium of pigs and that they mediate increases in the contractile rate and tension of the bladder [58], however; this assumption remains to be further investigated. 
The results of the current study showed that the potentiatory effect of alprostadil on ACh and EFS-induced contraction was inhibited in presence of sildenafil (low concentration) by almost $40 \%$ and $73 \%$ respectively. This indicates that there may be a crosstalk between $\mathrm{PGE}_{1}$ and $\mathrm{NO} / \mathrm{cGMP}$ pathway in detrusor muscles. At the cellular level, in detrusor muscles, $\mathrm{EP}_{1}$ and $\mathrm{EP}_{3}$ receptors may be the major contributors to the contractile effect of $\mathrm{PGE}_{1}$-analogue. The $\mathrm{EP}_{1}$ receptors are $\mathrm{G}_{\mathrm{q}}$-coupled which activates PLC resulting in formation of IP3 and DAG which in turn increase the intracellular $\mathrm{Ca}^{2+}$ level resulting in increasing the contractile response [59]. On the other hand, $\mathrm{EP}_{3}$ receptors may act via $\mathrm{G}_{\mathrm{q}}$ and also $\mathrm{G}_{\mathrm{i}}$ which inhibits cAMP and PKA activation resulting in decreasing detrusor muscles relaxation [14]. Therefore, sildenafil, upon activation of NO/cGMP pathway, results in elevating the intracellular level of cGMP and activating cGMP-dependent protein kinase (PKG) which interacts with $\mathrm{G}_{\mathrm{q}}$ pathway and cause inhibition of PLC contracting activity [60], which may inhibit the molecular pathways of $\mathrm{EP}_{1}$ and $\mathrm{EP}_{3}$ receptors. On the other hand, we cannot exclude the possible action of alprostadil on $\mathrm{EP}_{2}$ receptors which are Gs-coupled leading to the activation of adenyl cyclase (AC)/cAMP pathway and hence relaxation, this latter could have been masked in detrusor muscle by the stronger effect on $\mathrm{EP}_{1}$ and $\mathrm{EP}_{3}$ leading finally to contraction. Moreover, PKG is reported to activate PKA in smooth muscles [60] thus potentiating the probable relaxatory action of alprostadil on $\mathrm{EP}_{2}$, in addition to the inhibition of the molecular pathway of the contracting $\mathrm{EP}_{1 / 3}$ receptors (Figure 8). All these events may eventually result in inhibition of the potentiatory effect of alprostadil on detrusor muscles by sildenafil. Interestingly, Dveksler et al. (1989) reported that EFS of the rat urinary bladder provoked greater release of tissue $\mathrm{PGE}_{2}$ compared to basal levels [61], which may explain why the effect of the combination was more pronounced in experiments involving neurogenic stimulation. Measuring the level of cyclic nucleotides and NO as well as the expression of PGs receptors in detrusor muscles remains a limitation of the current study and requires further experiments to confirm the downstream pathway involved in the interaction of alprostadil with sildenafil in rat detrusor muscles.

Conclusions: Alprostadil, the synthetic $\mathrm{PGE}_{1}$ potentiated neurogenic and muscarinic responses of rat detrusor muscle as an indication of potential increase in micturition responses, consistent with previous clinical reports. The potentiatory effect of alprostadil was significantly inhibited in presence of the PDE-5 inhibitor - sildenafil- indicating that $\mathrm{PGE}_{1}$ pathway may have a crosstalk with NO/cGMP pathway. Elevated level of cGMP by sildenafil inhibits the activity of PLC involved in the pathway of alprostadil in detrusor muscles 
reducing thus its stimulatory effect on detrusor muscle. This observation, if proved in humans, may greatly add to the advantages of the combinatory use of sildenafil and alprostadil in clinical practice for a better management of erectile dysfunction as well as pulmonary hypertension, for which many combinatory treatments are under research including the same combination.

\section{Acknowledgements}

Part of this work was supported by Institut Francais in Egypt, and the Academy of Scientific Research \& Technology in Egypt (Sciences and Technology Development Fund) under the frame of "Imhotep Project $N^{\circ}: 31681 X L$ " and "STDF/IFE Project $N^{\circ} 30630$ ”.

\section{Conflict of Interest}

Authors declare no conflict of interest

\section{References:}

1. Patel AK, Chapple CR. Anatomy of the lower urinary tract. Surgery - Oxford International Edition 2008; 26(4): 127-32.

2. de Groat WC, Yoshimura N. Anatomy and physiology of the lower urinary tract. Handb Clin Neurol 2015; 130:61-108. Doi: 10.1016/b978-0-444-63247-0.00005-5.

3. Andersson KE, Arner A. Urinary bladder contraction and relaxation: physiology and pathophysiology. Physiol Rev 2004; 84(3):935-86. Doi: 10.1152/physrev.00038.2003.

4. Ding HL, Ryder JW, Stull JT, Kamm KE. Signaling processes for initiating smooth muscle contraction upon neural stimulation. J Biol Chem 2009; 284(23):15541-8. Doi: 10.1074/jbc.M900888200.

5. Uchiyama T, Chess-Williams R. Muscarinic receptor subtypes of the bladder and gastrointestinal tract. J Smooth Muscle Res 2004; 40(6):237-47. Doi: 10.1038/sj.bjp.0706560.

6. Hegde SS. Muscarinic receptors in the bladder: from basic research to therapeutics. $\mathrm{Br} \mathrm{J}$ Pharmacol 2006; 147(2):S80-7. Doi: 10.1038/sj.bjp.0706560.

7. Andersson KE. Potential Future Pharmacological Treatment of Bladder Dysfunction. Basic Clin Pharmacol Toxicol 2016; 119(3):75-85. Doi: 10.1111/bcpt.12577.

8. Abrams P, Cardozo L, Fall M, Griffiths D, Rosier P, Ulmsten U, et al. The standardisation of terminology of lower urinary tract function: report from the Standardisation Sub-committee of the International Continence Society. Am J Obstet Gynecol 2002; 187(1): 116-26. 
9. Lee T, Hedlund P, Newgreen D, Andersson KE. Urodynamic effects of a novel EP(1) receptor antagonist in normal rats and rats with bladder outlet obstruction. J Urol 2007; 177(4):1562-7. Doi: 10.1016/j.juro.2006.11.070.

10. Rahnama'i MS, van Koeveringe GA, van Kerrebroeck PE, de Wachter SG. The effect of indomethacin on the muscarinic induced contractions in the isolated normal guinea pig urinary bladder. BMC Urol 2013; 13:8. Doi: 10.1186/1471-2490-13-8.

11. Parajuli SP, Provence A, Petkov GV. Prostaglandin E2 excitatory effects on guinea pig urinary bladder smooth muscle: a novel regulatory mechanism mediated by largeconductance voltage- and Ca2+-activated K+ channels. Eur J Pharmacol 2014; 738:17985. Doi: 10.1016/j.ejphar.2014.05.042.

12. Granato C, Korstanje C, Guilloteau V, Rouget C, Palea S, Gillespie JI. Prostaglandin E2 excitatory effects on rat urinary bladder: a comparison between the $\beta$-adrenoceptor modulation of non-voiding activity in vivo and micro-contractile activity in vitro. Naunyn Schmiedebergs Arch Pharmacol 2015; 388(7):727-35. Doi: 10.1007/s00210015-1139-9.

13. Rahnama'i MS, van Kerrebroeck PE, de Wachter SG, van Koeveringe GA. The role of prostanoids in urinary bladder physiology. Nat Rev Urol 2012; 9(5):283-90. Doi: 10.1038/nrurol.2012.33.

14. Coleman RA, Smith WL, Narumiya S. International Union of Pharmacology classification of prostanoid receptors: properties, distribution, and structure of the receptors and their subtypes. Pharmacol Rev 1994; 46(2):205-29.

15. Tanaka I, Nagase K, Tanase K, Aoki Y, Akino H, Yokoyama O. Modulation of stretch evoked adenosine triphosphate release from bladder epithelium by prostaglandin $E(2)$. $J$ Urol 2011; 185(1):341-6. Doi: 10.1016/j.juro.2010.09.042.

16. Hanchanale V, Eardley I. Alprostadil for the treatment of impotence. Expert Opin Pharmacother 2014; 15(3):421-8. Doi: 10.1517/14656566.2014.873789.

17. Long WA and Rubin LJ. Prostacyclin and PGE1 treatment of pulmonary hypertension. Am Rev Respir Dis 1987; 136(3):773-6. Doi: 10.1164/ajrccm/136.3.773.

18. Ishii N, Watanabe H, Irisawa C, Kikuchi Y, Kawamura S, Suzuki K, et al. Studies on male sexual impotence. Report 18. Therapeutic trial with prostaglandin E1 for organic impotence. Nihon Hinyokika Gakkai Zasshi 1986; 77(6): 954-62.

19. Talosi G, Katona M, Racz K, Kertesz E, Onozo N, Turi S. Prostaglandin E1 treatment in patent ductus arteriosus dependent congenital heart defects. J Perinat Med 2004; 32(4):368-74. Doi: 10.1515/jpm.2004.069.

20. Drinda S, Neumann T, Pöhlmann G, Vogelsang H, Stein G, Wolf G, et al. The response of skin perfusion and of rheological and immunological variables to intravenous prostanoid administration in Raynaud's phenomenon secondary to collagenosis. Vasa 2005; 34(4):243-9. Doi: 10.1024/0301-1526.34.4.243.

21. Cacione DG, Macedo CR, Baptista-Silva JC. Pharmacological treatment for Buerger's disease. Cochrane Database Syst Rev 2016; 3:Cd011033. Doi: 10.1002/14651858.CD011033.pub3. 
22. Schellong SM, von Bilderling P, Gruss JD, Lawall H, Grieger F, Ney U, et al. Intravenous alprostadil treatment compared to oral pentoxifylline treatment in outpatients with intermittent claudication - results of a randomised clinical trial. Vasa 2017; 46(5):403-5. Doi: 10.1024/0301-1526/a000639.

23. Kondo A, Kobayashi M, Takita T, Narita H. Effect of prostaglandin on urethral resistance and micturition. Urol Res 1983; 11(1):19-22.

24. Morita T, Wheeler MA, Weiss RM. Age-related changes in contractile force of rabbit detrusor muscle to prostaglandin E1, E2 and F2 alpha. Urol Int 1987; 42(1):44-8. Doi: $10.1159 / 000281848$.

25. Palea S, Toson G, Pietra C, Trist DG, Artibani W, Romano O, et al. Pharmacological characterization of thromboxane and prostanoid receptors in human isolated urinary bladder. Br J Pharmacol 1998; 124(5):865-72. Doi: 10.1038/sj.bjp.0701903.

26. Linet OI, Ogrinc FG. Efficacy and safety of intracavernosal alprostadil in men with erectile dysfunction. The Alprostadil Study Group. N Engl J Med 1996; 334(14):873-7. Doi: 10.1056/nejm199604043341401.

27. The long-term safety of alprostadil (prostaglandin-E1) in patients with erectile dysfunction. The European Alprostadil Study Group. Br J Urol 1998; 82(4):538-43.

28. James MJ, Birmingham AT, Hill SJ. Partial mediation by nitric oxide of the relaxation of human isolated detrusor strips in response to electrical field stimulation. Br J Clin Pharmacol 1993; 35(4):366-72.

29. Yanai Y, Hashitani H, Hayase M, Sasaki S, Suzuki H, Kohri K. Role of nitric oxide/cyclic GMP pathway in regulating spontaneous excitations in detrusor smooth muscle of the guinea-pig bladder. Neurourol Urodyn 2008; 27(5):446-53. Doi: 10.1002/nau.20517.

30. Andersson KE, Uckert S, Stief C, Hedlund P. Phosphodiesterases (PDEs) and PDE inhibitors for treatment of LUTS. Neurourol Urodyn 2007; 26(6):928-33. Doi: 10.1002/nau.20485.

31. Gumrah A, Tanidir Y, Tinay I, Ozyurek M, Tarcan T. The effect of doxazosin and sildenafil citrate combination on bladder tissue contractility, alpha adrenergic receptor, and iNOS subtype expression in a male rat model of partially bladder outlet obstruction. Neurourol Urodyn 2017; 36(6):1479-87. Doi: 10.1002/nau.23155.

32. Aizawa N, Ito H, Sugiyama R, Fujimura T, Fukuhara H, Kume H, et al. Effects of Sildenafil, a Phosphodiesterase Type 5 Inhibitor, on the Primary Single Afferent Activity of the Rat Bladder. Low Urin Tract Symptoms 2017; 9(1):57-61. Doi: 10.1111/luts.12095.

33. Coyne KS, Sexton CC, Thompson CL, Milsom I, Irwin D, Kopp ZS, et al. The prevalence of lower urinary tract symptoms (LUTS) in the USA, the UK and Sweden: results from the Epidemiology of LUTS (EpiLUTS) study. BJU Int 2009; 104(3):35260. Doi: 10.1111/j.1464-410X.2009.08427.x.

34. Irwin DE, Kopp ZS, Agatep B, Milsom I, Abrams P. Worldwide prevalence estimates of lower urinary tract symptoms, overactive bladder, urinary incontinence and bladder 
outlet obstruction. BJU Int 2011; 108(7): 1132-8. Doi: 10.1111/j.1464410X.2010.09993.X

35. Lee M, Sharifi R. Non-invasive Management Options for Erectile Dysfunction When a Phosphodiesterase Type 5 Inhibitor Fails. Drugs Aging 2018; 35(3):175-87. Doi: $10.1007 / \mathrm{s} 40266-018-0528-4$.

36. Moncada I, Martinez-Salamanca J, Ruiz-Castañe E, Romero J. Combination therapy for erectile dysfunction involving a PDE5 inhibitor and alprostadil. Int J Impot Res 2018; 30(5):203-8. Doi: 10.1038/s41443-018-0046-2.

37. Luheshi GN, Zar MA. The effect of streptozotocin-induced diabetes on cholinergic motor transmission in the rat urinary bladder. Br J Pharmacol 1991; 103(3):1657-62.

38. Persson K, Igawa Y, Mattiasson A, Andersson KE. Effects of inhibition of the Larginine/nitric oxide pathway in the rat lower urinary tract in vivo and in vitro. $\mathrm{Br} \mathbf{J}$ Pharmacol 1992; 107(1):178-84.

39. Senbel AM, Hashad A, Sharabi FM, Daabees TT. Activation of muscarinic receptors inhibits neurogenic nitric oxide in the corpus cavernosum. Pharmacol Res 2012; 65(3):303-11. Doi: 10.1016/j.phrs.2011.12.002.

40. Wang YX, Cheng X, Pang CC. Vascular pharmacology of methylene blue in vitro and in vivo: a comparison with NG-nitro-L-arginine and diphenyleneiodonium. $\mathrm{Br} \mathrm{J}$ Pharmacol 1995; 114(1):194-202.

41. Gilmore NJ, Vane JR. Hormones released into the circulation when the urinary bladder of the anaesthetized dog is distended. Clin Sci 1971; 41(1):69-83.

42. Khalaf IM, Lehoux JG, Elshawarby LA, Elhilali MM. Release of prostaglandins into the pelvic venous blood of dogs in response to vesical distension and pelvic nerve stimulation. Invest Urol 1979; 17(3):244-7.

43. Nile CJ, Gillespie JI. Interactions between cholinergic and prostaglandin signaling elements in the urothelium: role for muscarinic type 2 receptors. Urology 2012; 79(1):240.e17-23. Doi: 10.1016/j.urology.2011.08.029.

44. Khalaf IM, Ghoneim MA, Elhilali MM. The effect of exogenous prostaglandins F2 alpha and E2 and indomethacin on micturition. Br J Urol 1981; 53(1):21-8.

45. Boie Y, Stocco R, Sawyer N, Slipetz DM, Ungrin MD, Neuschäfer-Rube F, et al. Molecular cloning and characterization of the four rat prostaglandin E2 prostanoid receptor subtypes. Eur J Pharmacol 1997; 340(2-3):227-41.

46. Ricciotti E, FitzGerald GA. Prostaglandins and inflammation. Arterioscler Thromb Vasc Biol 2011; 31(5):986-1000. Doi: 10.1161/atvbaha.110.207449.

47. Persson K, Alm P, Johansson K, Larsson B, Andersson KE. Nitric oxide synthase in pig lower urinary tract: immunohistochemistry, NADPH diaphorase histochemistry and functional effects. Br J Pharmacol 1993; 110(2):521-30.

48. Reitz A, Bretscher S, Knapp PA, Muntener M, Wefer B, Schurch B. The effect of nitric oxide on the resting tone and the contractile behaviour of the external urethral sphincter: 
a functional urodynamic study in healthy humans. Eur Urol 2004; 45(3):367-73. Doi: 10.1016/j.eururo.2003.10.002.

49. Brock G, Broderick G, Roehrborn CG, Xu L, Wong D, Viktrup L. Tadalafil once daily in the treatment of lower urinary tract symptoms (LUTS) suggestive of benign prostatic hyperplasia (BPH) in men without erectile dysfunction. BJU Int 2013; 112(7): 990-7. Doi: 10.1111/bju.12251.

50. Dell'Atti L. Efficacy of Tadalafil once daily versus Fesoterodine in the treatment of overactive bladder in older patients. Eur Rev Med Pharmacol Sci 2015; 19(9): 1559-63.

51. Reges R, D'Ancona C, Monica F, Antunes E. Effect of acute administration of sildenafil to rats with detrusor overactivity induced by chronic deficiency of nitric oxide. Int Braz J Urol 2013; 39(2):268-75. Doi: 10.1590/s1677-5538.ibju.2013.02.16.

52. Moon A. Influence of nitric oxide signalling pathways on pre-contracted human detrusor smooth muscle in vitro. BJU Int 2002; 89(9):942-9.

53. Longhurst PA, Briscoe JA, Rosenberg DJ, Leggett RE. The role of cyclic nucleotides in guinea-pig bladder contractility. Br J Pharmacol 1997; 121(8):1665-72. Doi: 10.1038/sj.bjp.0701328.

54. Oger S, Behr-Roussel D, Gorny D, Lebret T, Validire P, Cathelineau X, et al. Signalling pathways involved in sildenafil-induced relaxation of human bladder dome smooth muscle. Br J Pharmacol 2010; 160(5):1135-43. Doi: 10.1111/j.1476-5381.2010.00748.x.

55. Mathes $\mathrm{C}$, Thompson SH. The nitric oxide/cGMP pathway couples muscarinic receptors to the activation of Ca2+ influx. J Neurosci 1996; 16(5):1702-9.

56. Winder M, Tobin G, Zupancic D, Romih R. Signalling molecules in the urothelium. Biomed Res Int 2014; 2014:297295. Doi: 10.1155/2014/297295.

57. El-Metwally MA, Sharabi FM, Daabees TT, Senbel AM, Mostafa T. Involvement of alpha-receptors and potassium channels in the mechanism of action of sildenafil citrate. Int J Impot Res 2007; 19(6):551-7. Doi: 10.1038/sj.ijir.3901590.

58. Moro C, Tajouri L, Chess-Williams R. Adrenoceptor function and expression in bladder urothelium and lamina propria. Urology 2013; 81(1):211.e1-7. Doi: 10.1016/j.urology.2012.09.011.

59. Scott G, Leopardi S, Printup S, Malhi N, Seiberg M, Lapoint R. Proteinase-activated receptor-2 stimulates prostaglandin production in keratinocytes: analysis of prostaglandin receptors on human melanocytes and effects of PGE2 and PGF2alpha on melanocyte dendricity. J Invest Dermatol 2004; 122(5):1214-24. Doi: 10.1111/j.0022202X.2004.22516.x.

60. Xia C, Bao Z, Yue C, Sanborn BM, Liu M. Phosphorylation and regulation of Gprotein-activated phospholipase C-beta 3 by cGMP-dependent protein kinases. J Biol Chem. 2001; 276(23):19770-7. Doi: 10.1074/jbc.M006266200.

61. Dveksler G, Franchi AM, Gonzalez ET, Gimeno MA, Gimeno AL. Electric field stimulation alters the outputs of prostaglandins from isolated rat urinary bladder preparations. Influences of papaverine and tetradotoxin. Prostaglandins Leukot Essent Fatty Acids 1989; 36(2):65-8. 


\section{Legends to figure}

Figure (1). Representative tracings showing the effect of sildenafil $\left(10^{-8}-10^{-4} \mathrm{M}\right)$ on ACh $\left(10^{-4} \mathrm{M}\right.$, panel a) or electric field stimulation (EFS, $4 \mathrm{~Hz}$, panel b)-induced contraction of isolated rat detrusor muscles.

Figure (2). Effect of sildenafil $\left(10^{-8}-10^{-4} \mathrm{M}\right.$, panel a) and IBMX $\left(10^{-8}-10^{-4} \mathrm{M}\right.$, panel b) on ACh-induced contraction of isolated rat detrusor muscles at $10^{-4} \mathrm{M}$ ACh. Panel (c) represents percentage change induced by the tested compounds on ACh-induced contraction. Responses are expressed as mean \pm SEM. * denotes significant difference from control $(p<0.05)$. Values between parentheses indicate the number of animals.

Figure (3). Effect of sildenafil $\left(10^{-8}-10^{-4} \mathrm{M}\right.$, panel a) and IBMX $\left(10^{-8}-10^{-4} \mathrm{M}\right.$, panel b) on electric field stimulation (EFS)-induced contraction of isolated rat detrusor muscles at frequency of $4 \mathrm{~Hz}$. Panel (c) represents percentage change induced by the tested compounds on EFS-induced contraction. Responses are expressed as mean \pm SEM. * denotes significant difference from control $(p<0.05)$. Values between parentheses indicate the number of animals.

Figure (4). Effect of SNP $\left(10^{-9}-10^{-3} \mathrm{M}\right.$, panel a) on ACh-induced contraction of isolated rat detrusor muscles at $10^{-4} \mathrm{M}$ ACh. Panel (b) represents percentage change induced by SNP on ACh-induced contraction. Responses are expressed as mean \pm SEM. $*$ denotes significant difference from control $(p<0.05)$. Values between parentheses indicate the number of animals.

Figure (5). Effect of SNP $\left(10^{-9}-10^{-3} \mathrm{M}\right.$, panel a) on electric field stimulation (EFS)-induced contraction of isolated rat detrusor muscles at frequency of $4 \mathrm{~Hz}$. Panel (b) represents percentage change induced by SNP on EFS-induced contraction. Responses are expressed as mean

SEM.

* denotes significant difference from control $(p<0.05)$. Values between parentheses indicate the number of animals.

Figure (6). Effect of sildenafil $\left(10^{-8}-10^{-4} \mathrm{M}\right)$ on electric field stimulation (EFS)-induced contraction of isolated rat detrusor muscles in absence and presence of L-NAME $\left(10^{-4} \mathrm{M}\right)$, NPLA $\left(3 \times 10^{-5} \mathrm{M}\right), \mathrm{MB}\left(10^{-5} \mathrm{M}\right)$ (panel a), or atropine $(0.1 \mu \mathrm{M}$, panel b) at frequency of $4 \mathrm{~Hz}$. Responses are expressed as mean \pm SEM. * denotes significant difference from sildenafil $(p<0.05)$. Values between parentheses indicate the number of animals.

Figure (7). Effect of sildenafil $\left(10^{-7} \mathrm{M}\right)$ on alprostadil $\left(10^{-9}-10^{-5} \mathrm{M}\right)$-induced potentiation of ACh (panel a) or electric field stimulation (EFS, panel b)-induced contraction of isolated rat detrusor muscles at concentration of $10^{-4} \mathrm{M}$ ACh or frequency of $4 \mathrm{~Hz}$. Responses are expressed as mean \pm SEM. * denotes significant difference from control. \# denotes significant difference from alprostadil $(p<0.05)$. Values between parentheses indicate the number of animals. 
Figure (8). Proposed mechanism of interaction between alprostadil and sildenafil in isolated rat detrusor muscle (modified from Xia et al.,2001)[54]

$\mathrm{AC}=$ adenylyl cyclase, $\mathrm{ATP}=$ adenosine triphosphate, $\mathrm{Ca}^{2+}=$ calcium, $\mathrm{cAMP}=$ cyclic adenosine monophosphate, $\mathrm{cGMP}=$ cyclic guanosine monophosphate, $\mathrm{DAG}=$ diacylglycerol, $\mathrm{EP}=$ prostaglandin $\mathrm{E}$ receptor, $\mathrm{G}_{\mathrm{q}, \mathrm{s}}=\mathrm{G}$-protein coupled receptors, $\mathrm{GTP}=$ guanosine triphosphate, IP3= inositol triphosphate, $\mathrm{K}^{+}=$potassium, $\mathrm{NO}=$ nitric oxide, $\mathrm{PKA}=\mathrm{cAMP}-$ dependent protein kinase, $\mathrm{PKG}=\mathrm{cGMP}-$ dependent protein kinase, $\mathrm{PLC}=$ phospholipase $\mathrm{C}$, $\mathrm{sGC}=$ soluble guanylyl cyclase 

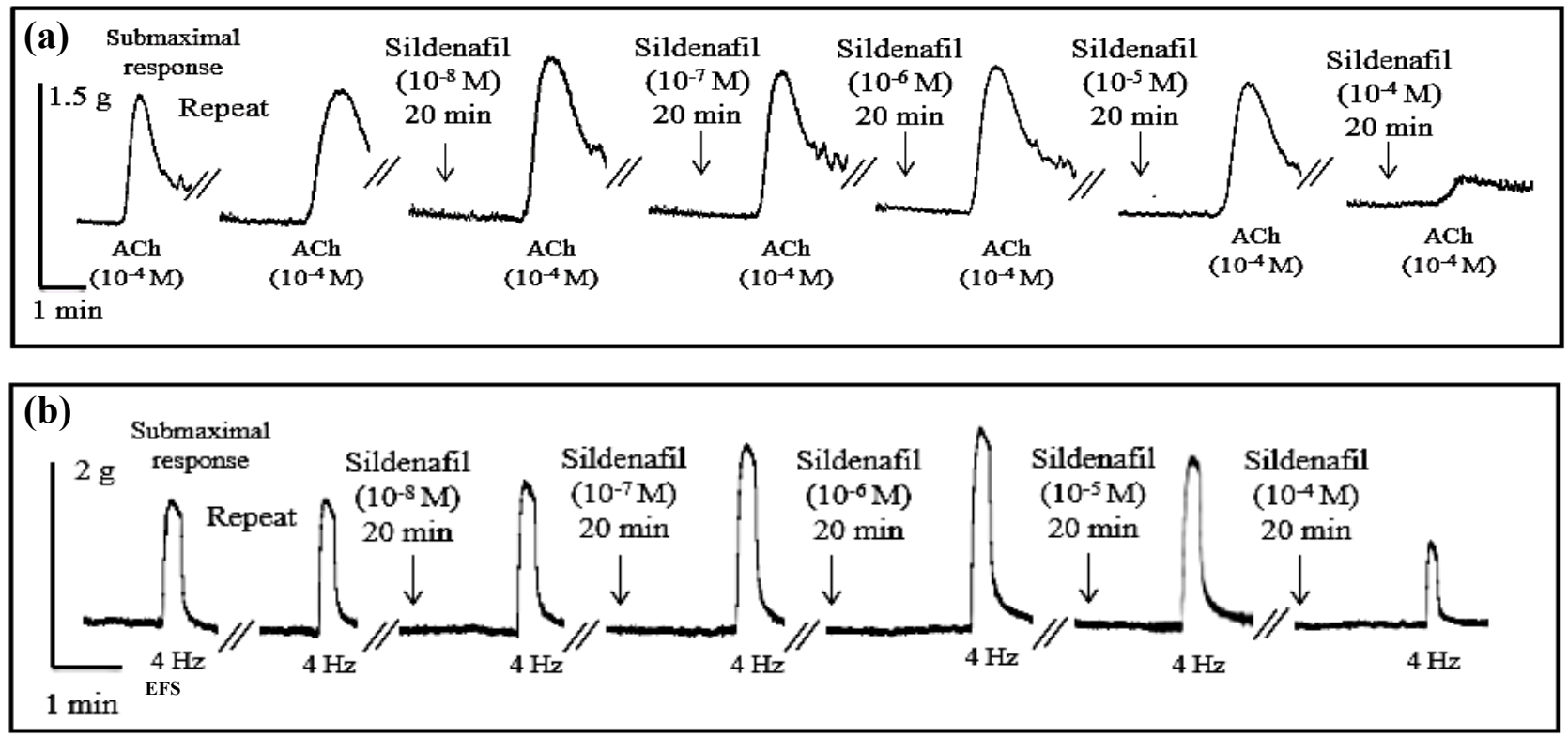

Figure (1) 

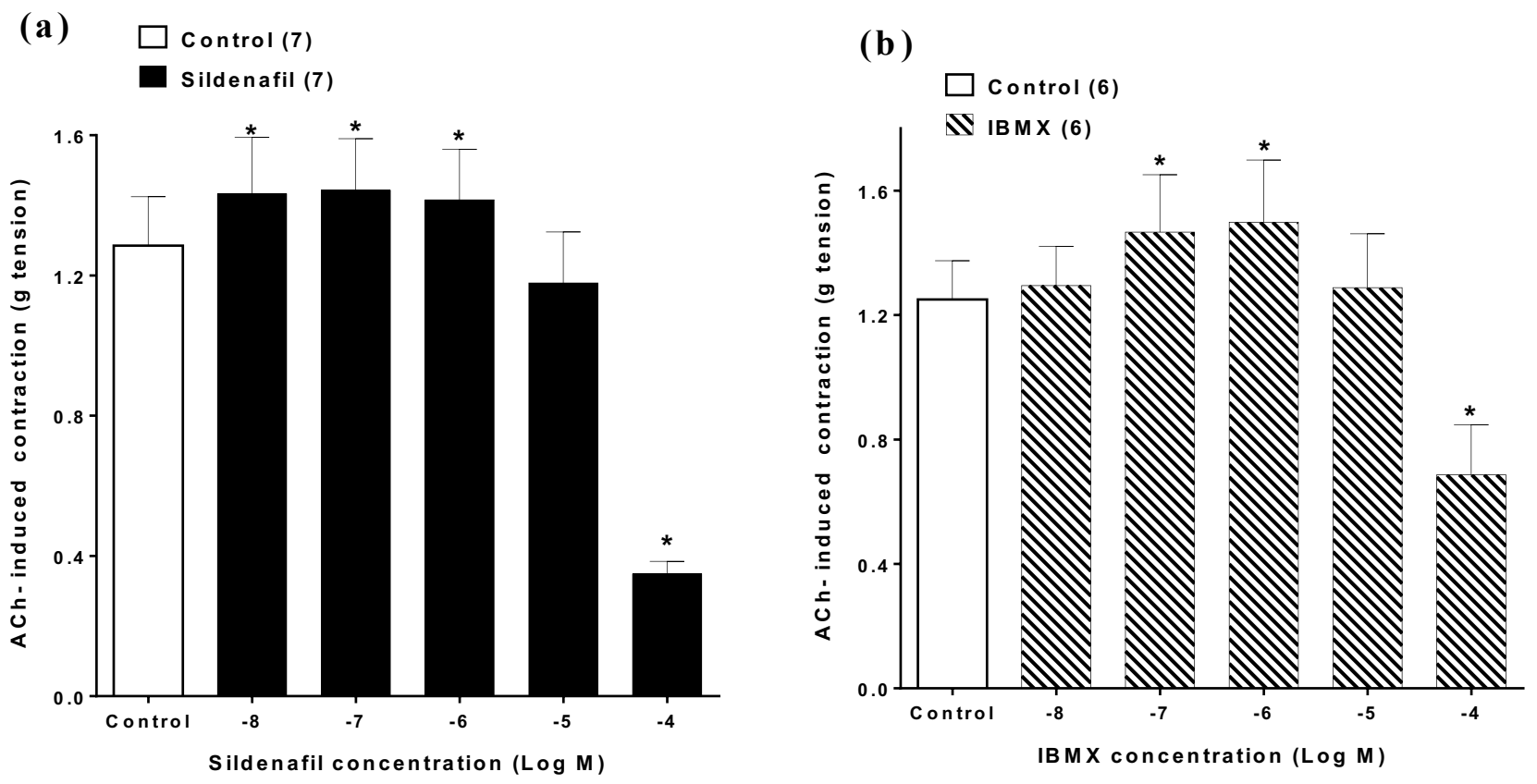

(c)

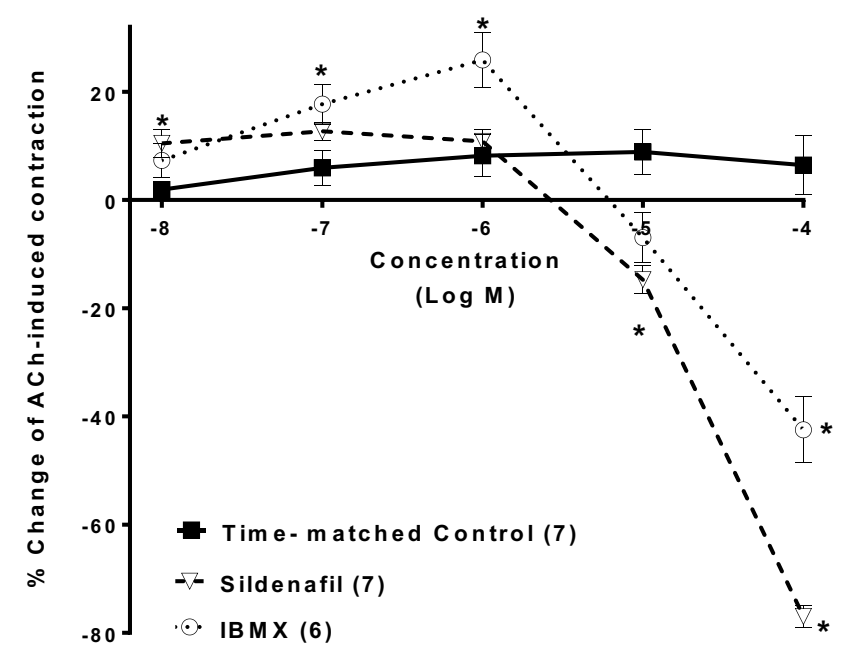

Figure (2) 
(a)

Control (6)

- Sildenafil (6)

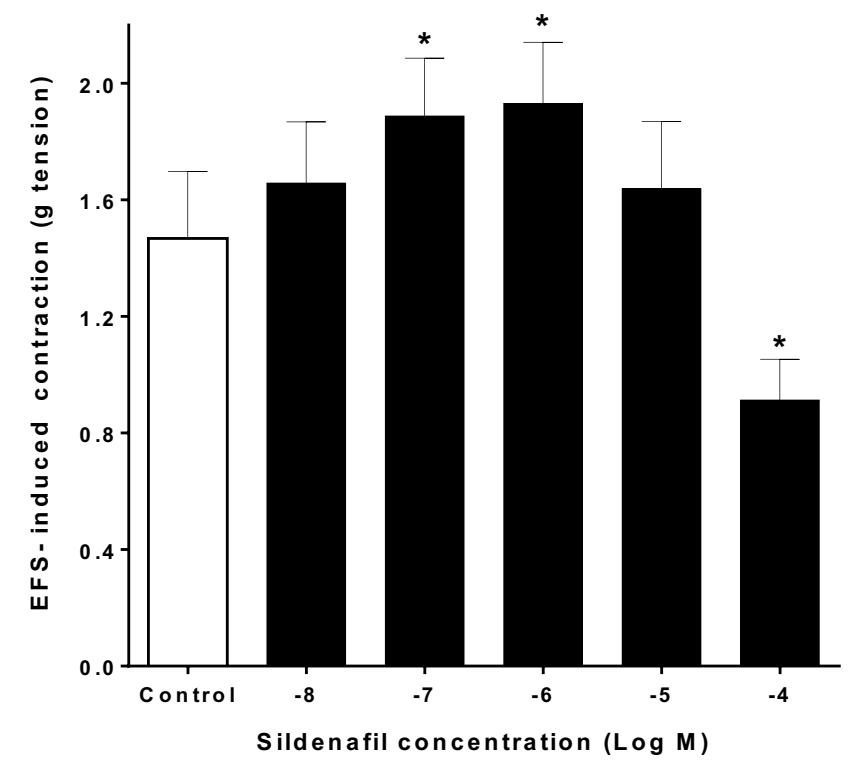

(b) Control (6) N IBMX (6)

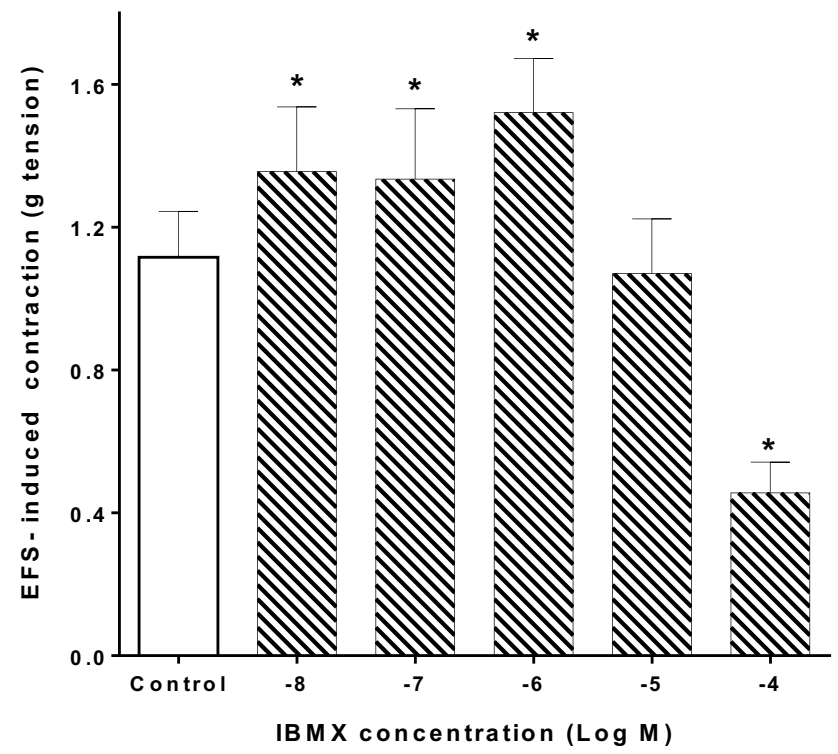

(c)

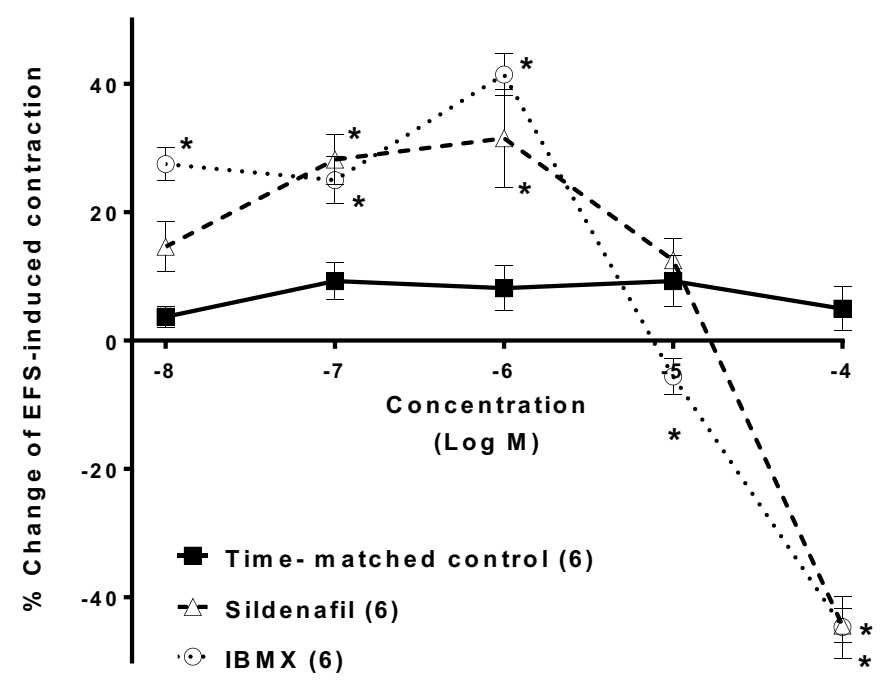

Figure (3) 
(a) Control (6)

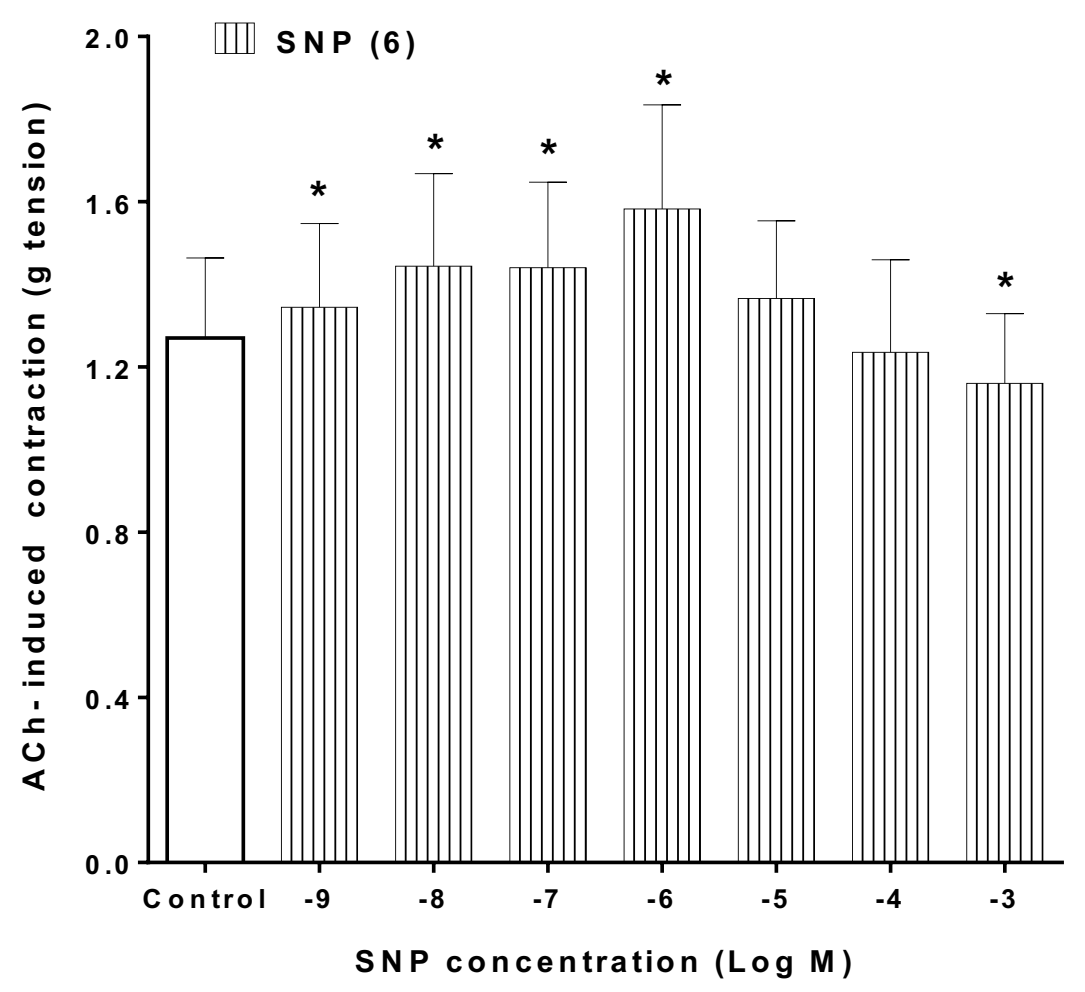

(b)

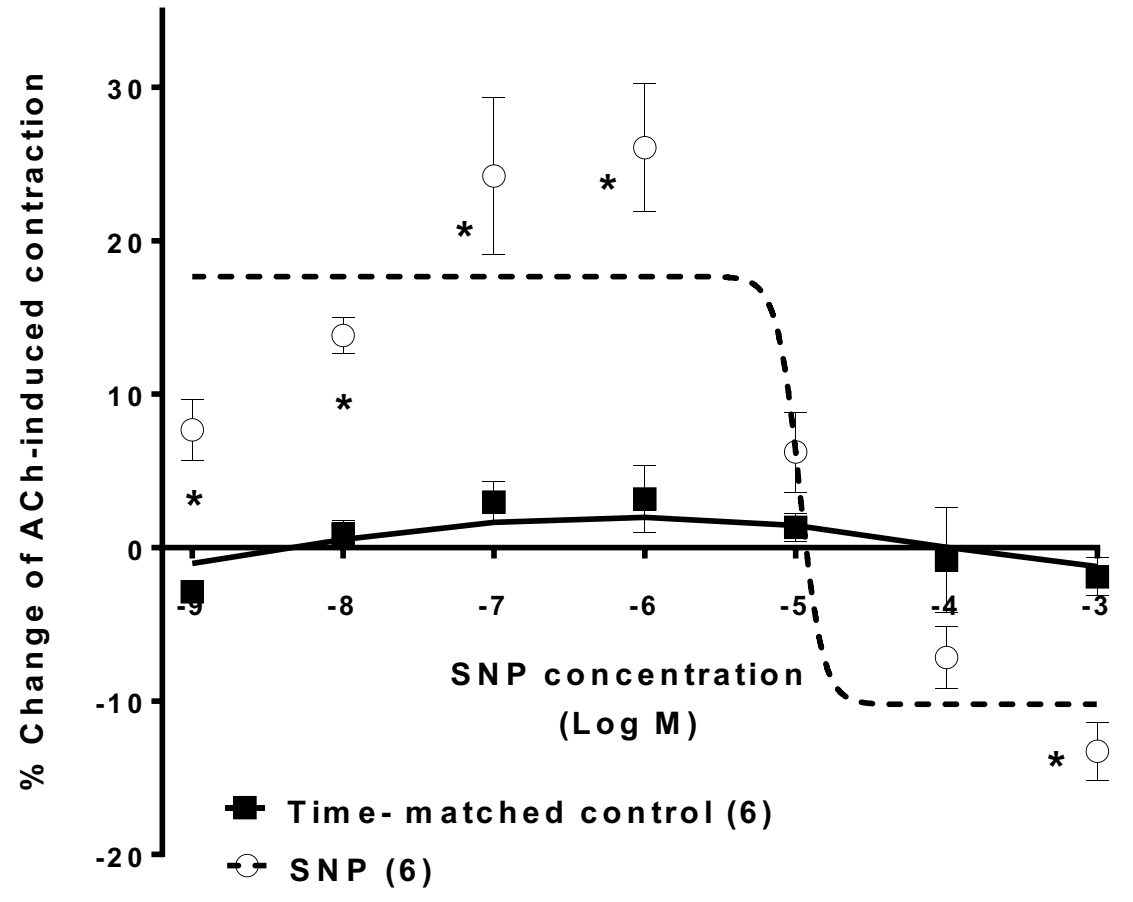

Figure (4) 


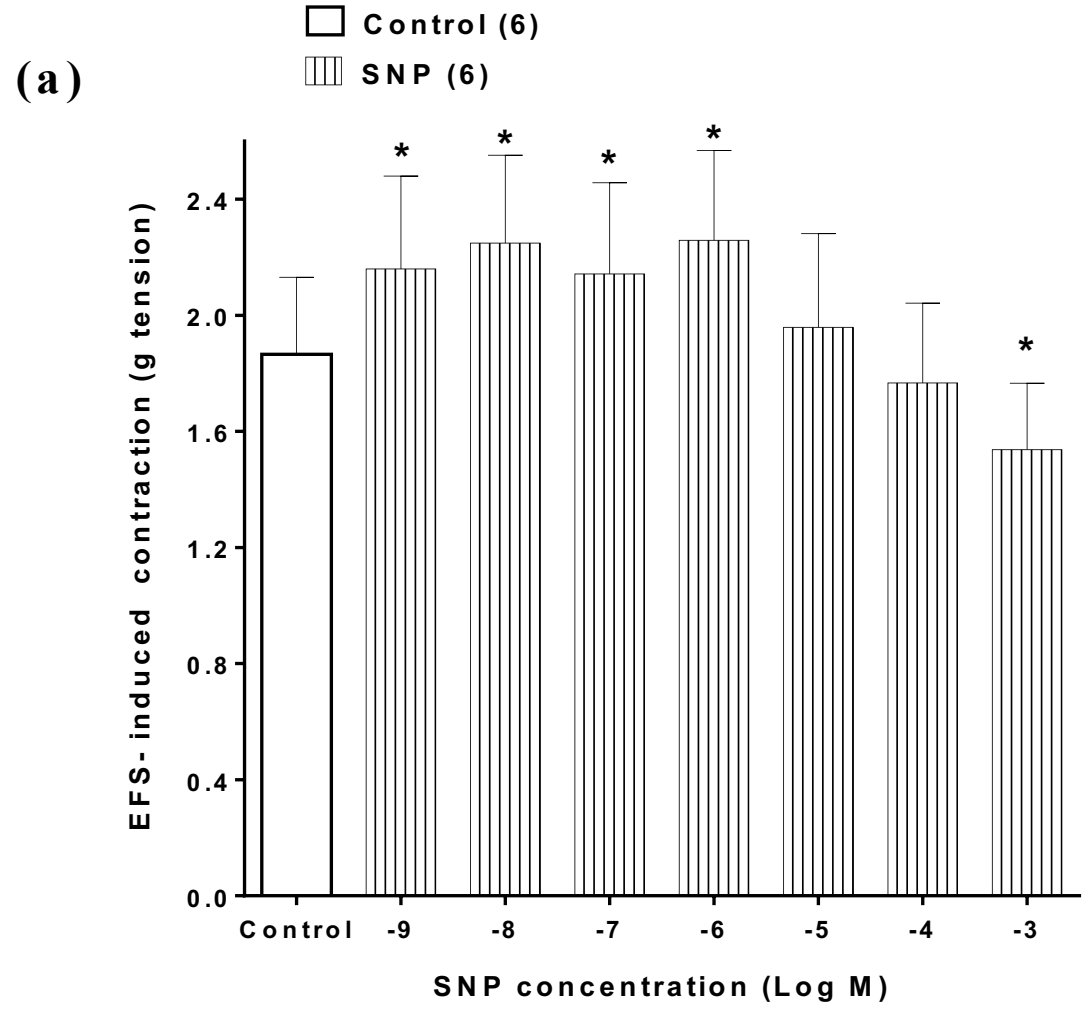

(b)

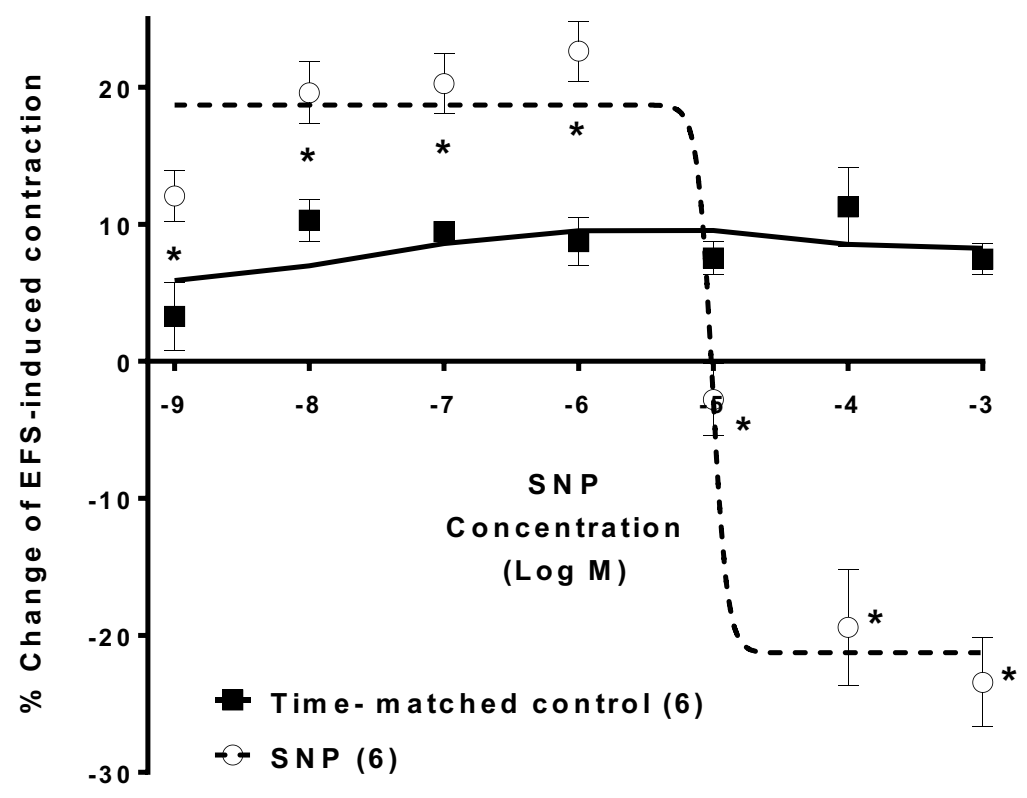

Figure (5) 


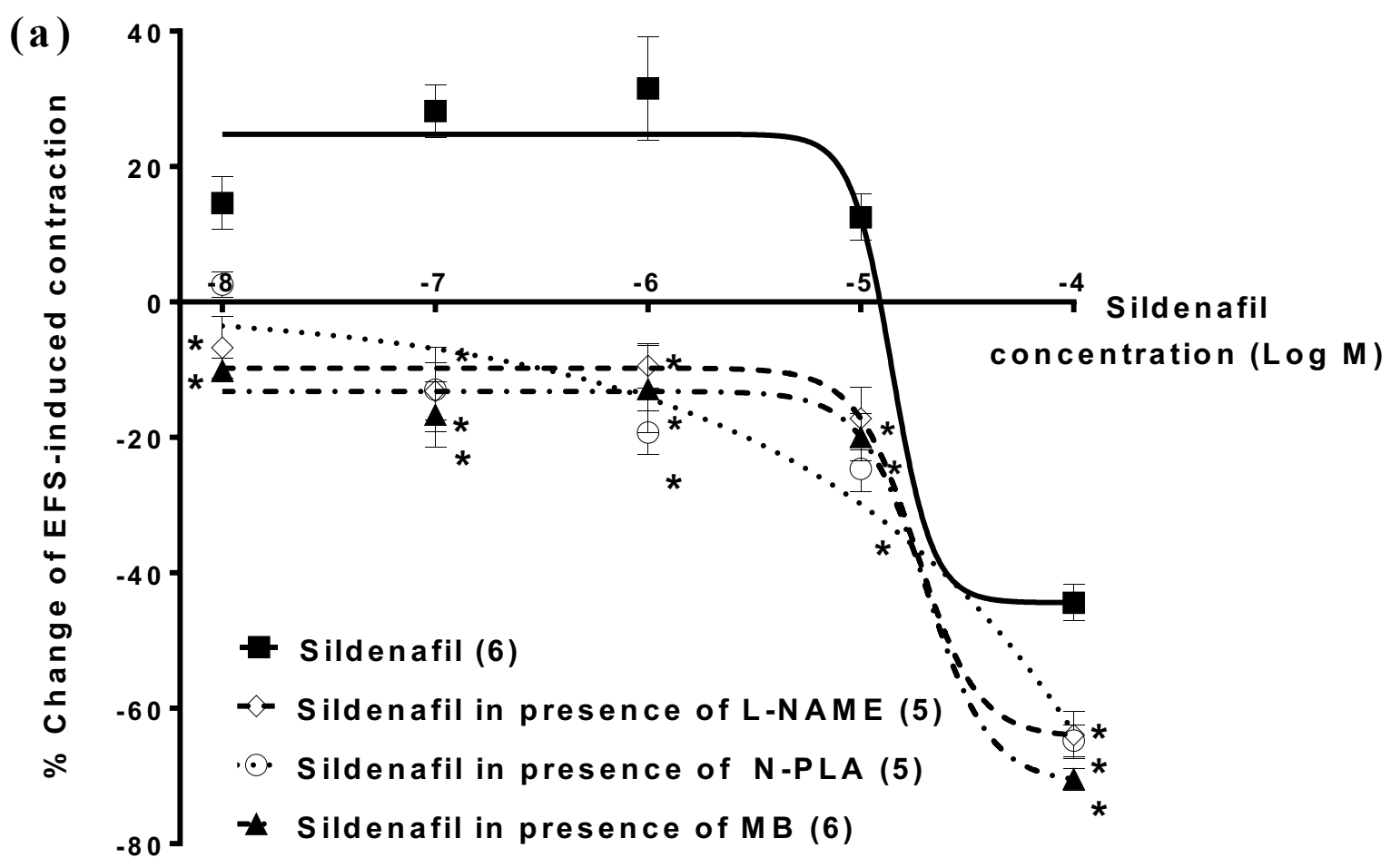

(b)

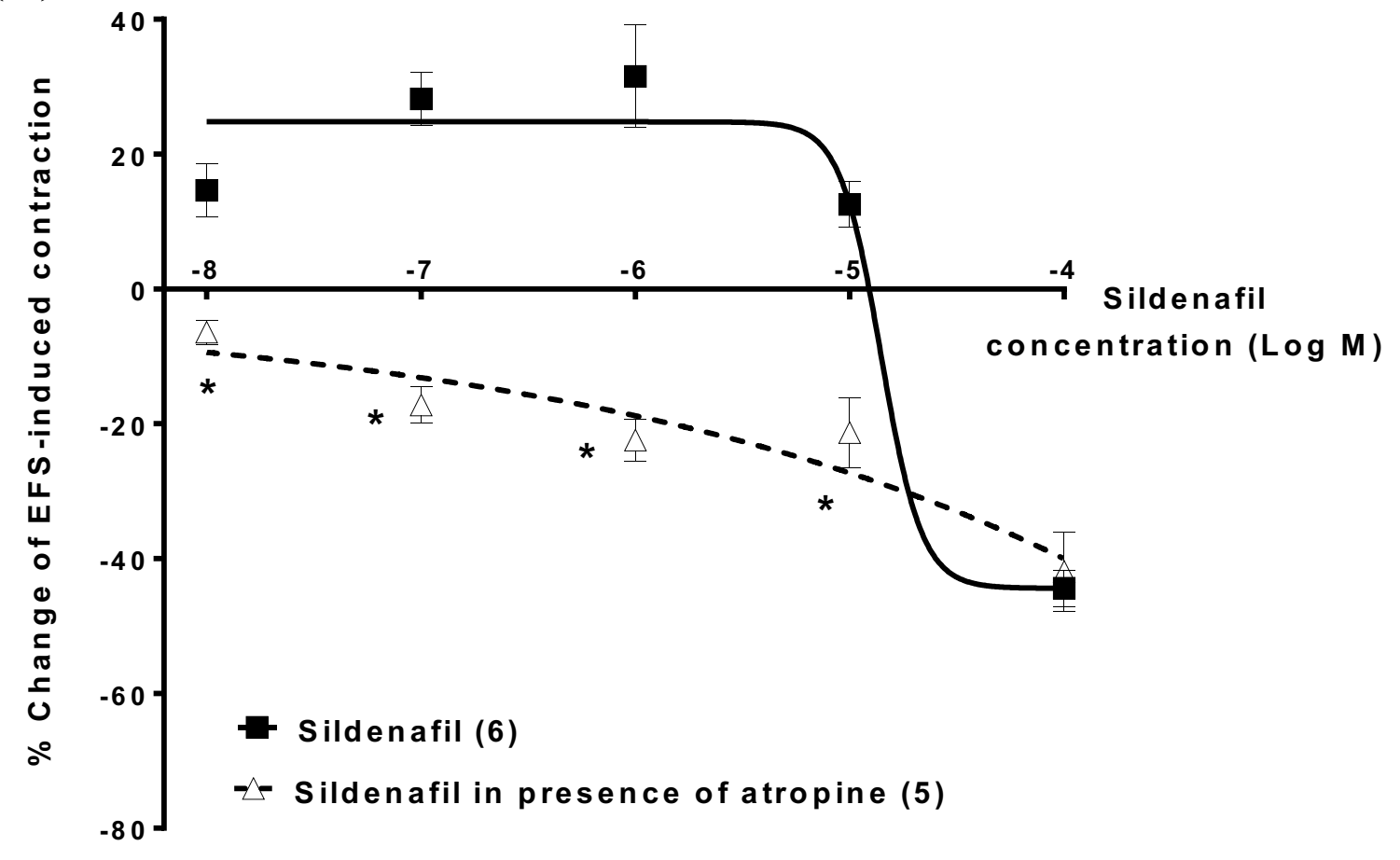

Figure (6) 
(a)

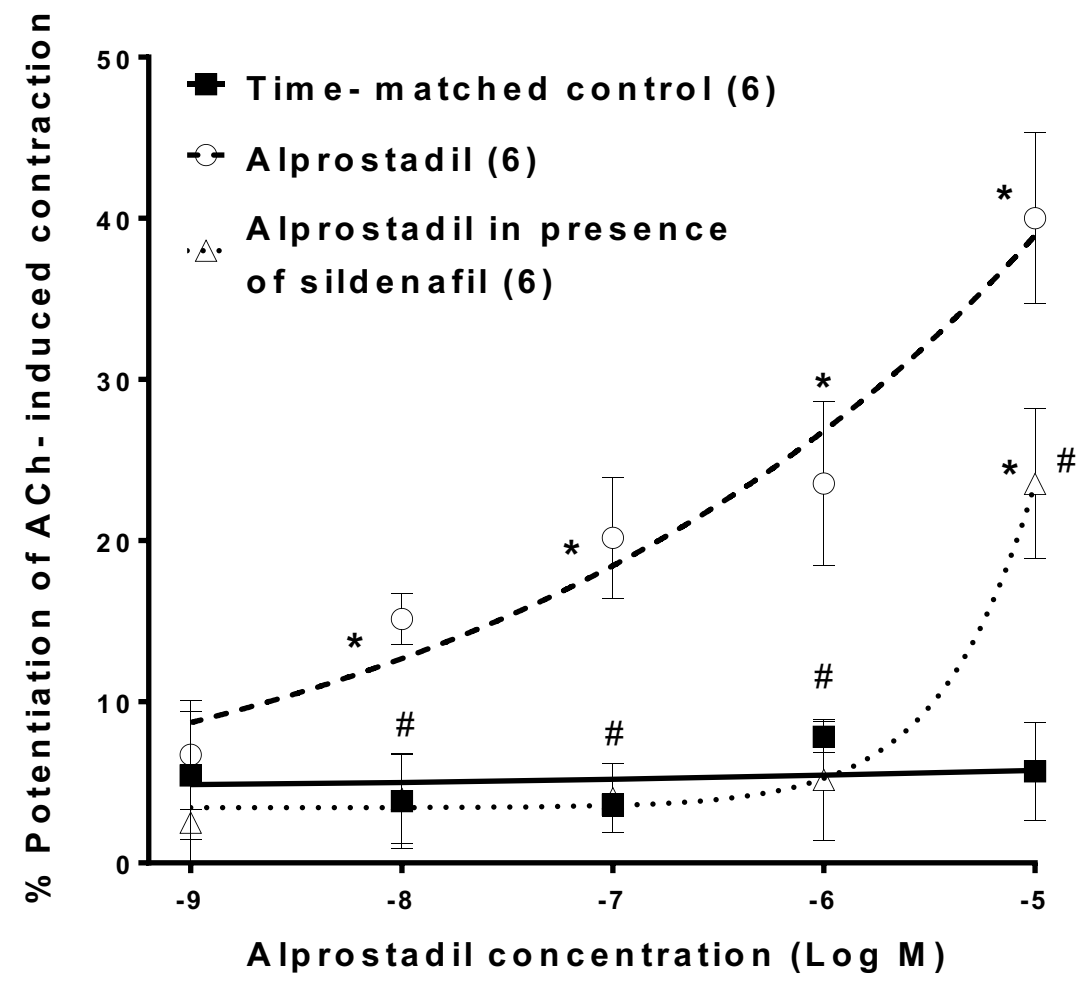

(b)

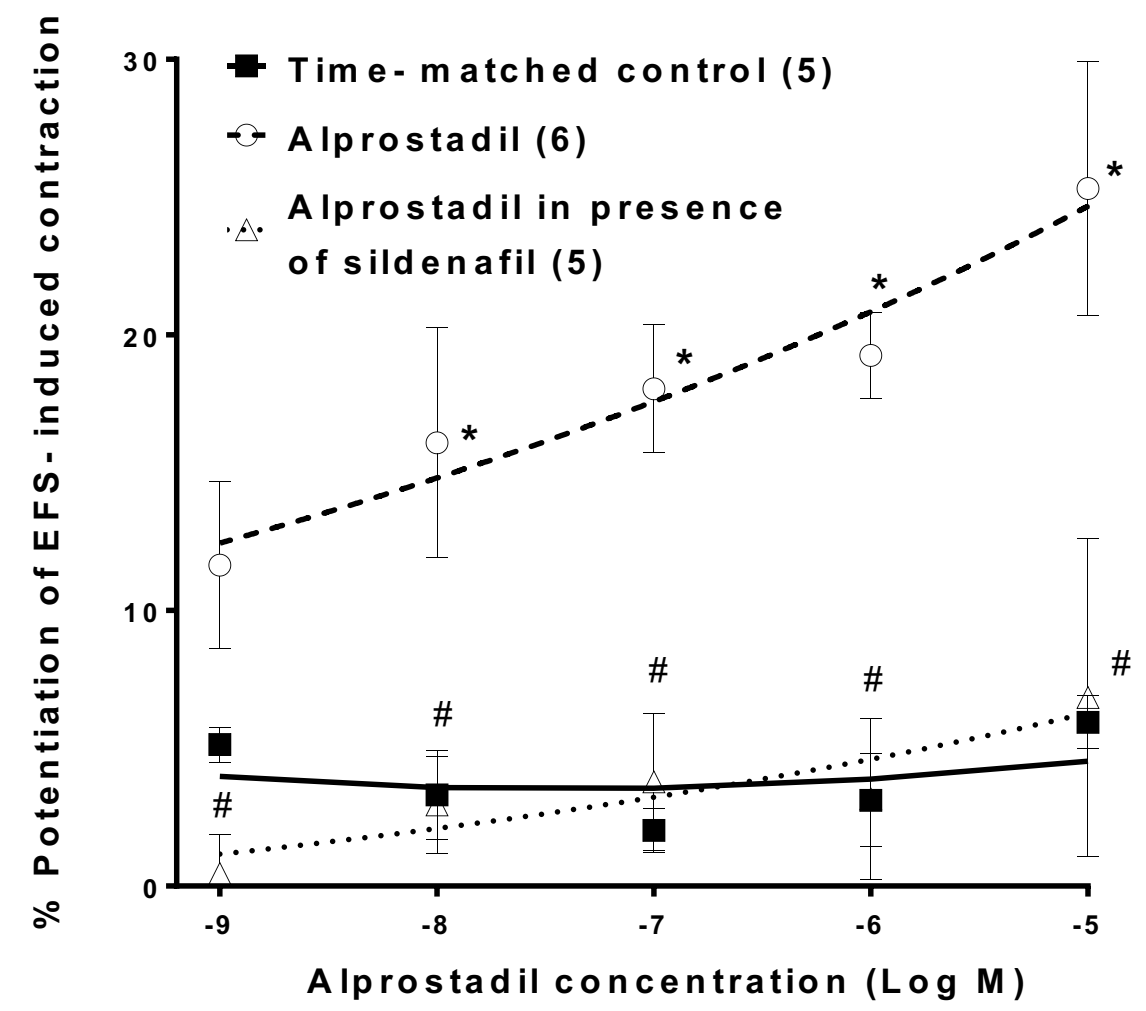

Figure (7) 


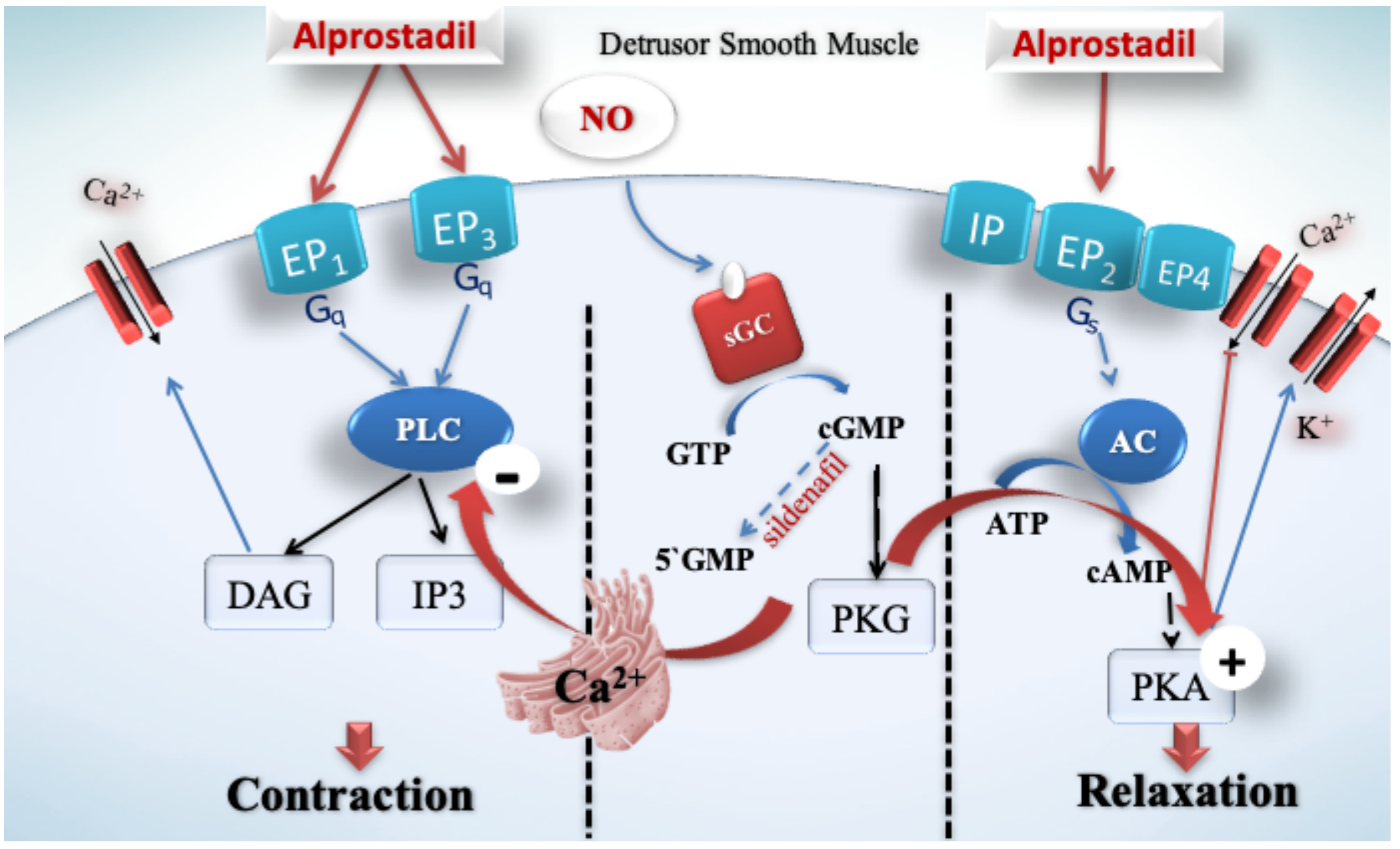




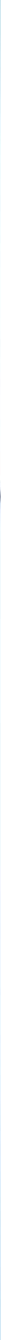

